\title{
Exploring Occupational Psychological Health Indicators Among Construction Employees: A Study In Ghana
}

Genevieve Ataa Fordjour*, Albert P. C. Chan

Department of Building and Real Estate, The Hong Kong Polytechnic University, China

Article Info

\section{Article Notes}

Received: March 3, 2019

Accepted: April 9, 2019

\section{*Correspondence:}

Dr. Genevieve Ataa Fordjour, PhD candidate, Department of Building and Real Estate, The Hong Kong Polytechnic University, Hong Kong, China; Telephone No: (852) 34008112; Email: genevievefordjour@gmail.com.

(c) 2019 Fordjour GA. This article is distributed under the terms of the Creative Commons Attribution 4.0 International License.

\section{Keywords}

Occupational psychology

Psychological health

Psychological indicators

Construction professionals

Construction workers

Ghanaian construction
Abstract

This study aims to explore the need for occupational psychological health interventions in the construction industry by identifying occupational psychological health conditions among construction employees. To achieve this aim, 300 questionnaires were equally distributed to purposively selected construction professionals and construction trade workers in Ghana. Four main constructs namely: individual lifestyle, psychosocial symptoms, physiological conditions, and work attitudes, were assessed to identify occupational psychological health conditions among the two construction working groups. These four main constructs were further divided into 20 occupational psychological health indicators. Quantitative analysis of the data was done, and a comparison made between the scores obtained from the two construction groups. Using the measures of individual lifestyle and work attitudes, the construction trade workers were found to be more prevalent in adverse occupational psychological health conditions than the construction professionals. The measures of psychosocial symptoms and physiological conditions, however, revealed no much statistically significant differences between the mean scores obtained from the two construction groups. Each of the two-construction group had their participants experiencing some form of adverse occupational psychological health conditions. Differences between the two groups in terms of factors such as task levels, role demands and income levels, are likely to influence their different level of vulnerability to psychological disorders. This study recommends some psychological health interventions to enhance the well-being of all construction employees. The findings from this study form the basic step in designing a preventive occupational psychological health model, with the aim to promote a psychologically safe and healthy construction workplace.

\section{Introduction}

Occupational psychological issues are inevitable and have an integral component in the performance, sequential growth, and development of every organization ${ }^{1}$. Organizational pressure of keeping cost and expenditure at the minimum level, while maximizing profits, as well as doing more in less time, coupled with numerous personal roles to be fulfilled in ones' relationship and work, could have a toll on the psychological health condition of an employee $^{2}$. Adverse psychological health conditions such as stress, depression, and anxiety could have devastating consequences on the construction employee as well as the construction industry ${ }^{3,4}$. On the other hand, positive psychological conditions such as happiness, fulfillment, and enthusiasm could have benefits on both the employee's general well-being and the organization's job outcome $\mathrm{e}^{5}$.

Given that the construction work is complicated, dynamic, crisis-ridden and involves high speed, construction employees 
could be prevalent to adverse occupational psychological conditions ${ }^{6,7}$. Construction works in Ghana, for instance, could be very stressful and involves working at height, underground, in spaces that are confined and at a proximity close to falling objects or materials ${ }^{8}$. It was revealed in the study by Adei and Kunfaa ${ }^{9}$ that, the common occupational health diseases of workers in Ghana are: musculoskeletal disorders (example lower back pain), respiratory tract infections, asthma, conjunctivitis and hearing problems. As a developing country, the atmosphere in Ghana also appears to be a breeding ground conducive enough for employees' psychological health problems. Inadequate resources and half-hearted interventions from some officials in Ghana also include the possible causes. Similar to the findings of Lazarus, et. al. ${ }^{10}$, construction employees' psychological illbeing conditions can also be attributed to daily incidents and nuisances such as debts, rent, school fees, side effects of medicines, traffic congestion and pressure to get too many things done in less than enough time.

Construction employees specifically construction professionals and construction trade workers are essential contributors to a construction project's outcome, in terms of time, quality and $\cos ^{11,12}$. The employees categorized as construction professionals include architects, engineers, quantity surveyors, and the likes. The construction trade workers group also include carpenters, masons, plumbers, and the likes. Adverse psychological health conditions of construction employees could have both direct and indirect cost with several implications on the interpersonal relationship, task and project performance of the construction industry ${ }^{7}$. Some of the implications for the construction industry could include: increases in turnover rate, decreases in job satisfaction, a general deterioration in work productivity and poor performance outcomes ${ }^{4,11,13}$.

The Chartered Institute of Building (CIOB) revealed in their study conducted in 2006 that about $70 \%$ of employees in the construction industry suffer from adverse psychological health conditions such as stress, depression, and anxiety ${ }^{14}$. A study by the Health and Safety Executive ${ }^{15}$ also revealed that about 10.5 million workdays could be lost yearly to work-related psychological health and physical illness. The effects of adverse psychological health conditions of construction employees could also include ineffectiveness, low productivity, poor communication, absenteeism, low morale, high job turnover, poor work relations, poor organizational climate, and accidents in the workplace ${ }^{16,17}$. Working conditions, work methods, working relations, and time schedules are some of the construction work-related factors that could expose employees to adverse occupational psychological health conditions $s^{6}$. The main components of construction work-related factors leading to psychological health conditions in the workplace could be categorized under organizational, task, physical and personal factors ${ }^{18}$.
Albeit the number of research works that have been carried out on the occupational health in Ghana and other jurisdictions, there has been little research attention on the occupational psychological health conditions of both construction professionals and trade workers in the construction industry. Research in occupational health investigates mainly a single aspect of occupational psychological health conditions which is stress. There is also less research attention on the construction trade workers, and most research works are carried out using construction professionals as the target respondents for the study ${ }^{6,19}$.

This research seeks to explore the indicators of occupational psychological health conditions among both construction professionals and construction trade workers in Ghana. This research study forms part of the necessary steps in developing a preventive psychological health management model for all employees in the construction industry. This model will help enhance the well-being of construction employees, which will lead to an optimized level of productivity and good job performance. The findings from the research study will, therefore, add to the body of knowledge on occupational psychology in the construction industry.

\section{Background of Research}

Studies in occupational psychology have revealed that psychological health conditions could have adverse consequences on the individual employee's physical, mental and social well-being ${ }^{2,3}$. The psychological health condition of employees could be described as a condition in which the indicators are relatively constant; however, the psychological health condition itself could be dynamic ${ }^{5,20}$. Employees' subjective evaluations of their work situations can influence their occupational psychological health condition $^{21}$. Indicators of psychological health condition could be categorized under physical, mental and emotional symptoms $^{22,17}$. Occupational psychological health conditions of employees usually emanate from many interpersonal and organizational factors ${ }^{23}$.

The positive occupational psychological health condition also known as psychological well-being is usually based on individuals' subjective feelings and experiences ${ }^{5}$. Psychologists have classified the main components of occupational psychological well-being into eudaimonic and hedonic $^{24}$. The eudaimonic aspect of psychological wellbeing focuses on the realization and fulfillment of human potential ${ }^{3}$. Occupational research on work engagement and job meaning gives an understanding of the eudaimonic element of psychological well-being ${ }^{24}$. The eudaimonic element can, therefore, be identified in terms of workers' feelings of purpose and fulfillment ${ }^{25}$. The hedonic element of psychological well-being has to do with the individual's 
experiences of pleasure and the balance of negative with positive thoughts ${ }^{24}$. Occupational research on job satisfaction provides an understanding of the hedonic element of workers' psychological well-being ${ }^{3}$.

The adverse psychological health conditions also known as psychological ill-being conditions are known to exist in all professions, with the common ones been stress, depression, and anxiety ${ }^{26}$. Using the Depression, Anxiety and Stress Scale (DASS), psychological ill-being conditions have been categorized into five subgroups, and these are normal, mild, moderate, severe and extremely severe levels of psychological ill-being conditions ${ }^{27,28}$. Every employee usually goes to work with a certain level of predisposition towards psychological ill-being conditions, which could emanate from feelings of pressure at the workplace ${ }^{29}$. Occupational psychological ill-being conditions such as burnout are not harmful, but high levels could have detrimental effects on behavioral and organizational outcomes of the construction industry ${ }^{11}$. For instance, a person experiencing role strain or stress may have adverse reactions such as frustration, with the employee failing assignments and eventually leaving the construction organization. Adverse psychological health conditions of employees are also known to occur when there is a disparity between what is expected or demanded from the employee, and the employee's ability to handle the circumstances ${ }^{30}$.

Many types of physical ailments have been linked with adverse psychological health conditions such as high blood pressure, heart attack, heart disease, peptic ulcer, headache, pain in the neck, asthma, and cancer ${ }^{31}$. Some physical and emotional indicators of adverse occupational psychological health conditions also include: gastrointestinal disorders, migraine, skin problems, diabetes, hypertension, ulcers, infectious diseases, headaches, chest pain, back pain, anxiety, boredom, trembling, low self-esteem, forgetfulness, depression, anger, apathy, worry, and fatigue ${ }^{32,16}$. Construction employees may also show behavioral deviations of adverse psychological health conditions such as overeating, loss of appetite, excessive smoking, alcohol abuse, sleeping disorders, emotional outbursts, violence and aggressive behaviors ${ }^{17,22}$.

These critical issues of occupational psychological disorders made it imperative that the research aimed to explore the indicators of occupational psychological health conditions among construction employees. The psychological health indicators can be categorized under four main constructs namely; individual lifestyle, psychosocial symptoms, physiological conditions and work attitudes $^{20}$.

\section{Individual lifestyle}

Exercise is well known to be one of the effective ways to boost one's mental health, general health and well-being ${ }^{17}$. Individuals who hardly engage in some form of exercise could be more prone to the conditions of stress, depression and anxiety ${ }^{20}$. There is now a very large body of evidence that suggests that good eating habit is as important to ones' psychological well-being as it is to general health ${ }^{33}$. Excess or lower body weight is associated with increased risks of developing a variety of chronic illness, most of which can be linked with psychological disorders ${ }^{1}$. Alcohol consumption undoubtedly has an impact on the physical and mental health of the consumer ${ }^{17}$. Abusing drugs impede the brain circuits as it affects the functionality of brain circuits and also interferes with other bodily functions ${ }^{20}$. Poor sleep is known to be associated with physical problems such as a weakened immune system and mental health problems such as anxiety and depression ${ }^{16}$. Psychological ill-being conditions can result in sudden changes in a person's behavior, leading to unhealthy habits ${ }^{12}$.

\section{Psychosocial symptoms}

Stress is one of the most common psychological ill-being conditions among employees ${ }^{11}$. Depression is a disease that can affect everything one does in daily life and every aspect of one's life ${ }^{28}$. Anxiety could be described as an emotional response proportional to a perceived danger or risks ${ }^{27}$. Resilience is often discussed as the aspect of mental health and coping that is paramount in adverse circumstances ${ }^{20}$. Negative actions of harassment or violent can have physical and emotional consequences ${ }^{23}$. Abuse can cause the victim to experience one or more mental or medical illnesses ${ }^{3}$.

\section{Physiological conditions}

A heart problem can lead to psychological conditions of anxiety and depression ${ }^{33}$. Temporary incapacity to work due to a musculoskeletal disorder also increase the risk of psychological disorders ${ }^{18,16}$. Poor health can increase the risk of mental health problems ${ }^{33}$. Personal medical history can sometimes be a sufficient cause of a person's psychological ill-being conditions ${ }^{21}$.

\section{Work attitudes}

Previous investigations have shown that work happiness is directly related to mental health, depression and social action ${ }^{24}$. Commitment to work has a direct relationship to well-being and psychological conditions of stress $^{25}$. Employees who are advocates are usually mentally alert, inclusive, engaging and enthusiastic about everything regarding their work ${ }^{20}$. Persons who lack advocacy usually do not express their views or concerns on issues important to them, and these could make them vulnerable to adverse psychological health conditions ${ }^{2,3}$.

\section{Research Methods}

To explore the indicators of occupational psychological 
health conditions among construction professionals and construction trade workers, this study adopted the methods of survey questionnaires. A target of 300 participants comprising of 150 construction professionals and 150 construction trade workers were set for this study. Large sample size of 100 and above are common with studies conducted in the construction industry ${ }^{4,13,16}$. Structured questionnaires were distributed face to face to construction employees in Ghana until the target of 300 respondents were achieved. The respondents were selected from thirty-two (32) construction companies registered under either one of the four construction works classifications in Ghana, namely: D1K1, D2K2, D3K3, and D4K4 construction industries. These classifications are based on the size of the construction company. The large-scale construction firms belong to D1K1, the medium scale construction firms belong to D2K2 or D3K3 and the small-scale construction firms belong to D4K4 works classification.

A non-probability sampling technique, specifically the purposive sampling method was adopted in selecting the research participants. The participants in the study were selected on the basis that (1) they have work experience in the Ghanaian construction industry and (2) they belong to either a construction professionals' group or a construction working trade. The construction professionals group comprised of architects, engineers, quantity surveyors, contractors, supervisors, construction managers, and project managers. The construction trade working group also include carpenters, masons, plumbers, steel benders and the likes.

\section{Ethical Considerations}

Appropriate research ethics are required to be adhered to by all researchers for every research work carried out and this study is not an exemption. Some ethical considerations for this study included allowing respondents voluntarily to participate in the study based on their free will, without any form of coercion or force implemented. The consent of each participant was also sought to include their responses in this study. The prospective respondents were also assured that the results of this study will not place any of the respondents at the risk of criminal or civil liability nor damage the respondents' financial standing, employability or reputation. Anonymity and personal information of the participants were therefore treated with confidentiality.

\section{Research Materials}

The World Health Organization (WHO $)^{33}$, advocated that an individual's psychological health condition should be assessed based on the complete mental, physical and social well-being of the person, and not merely the absence of a particular condition, disease or infirmity. Adverse occupational psychological health condition such as workaholism and burnout can lead to impaired well-being like fatigue, chronic tension, sleep problems and other physical diseases ${ }^{34}$. Indicators of adverse psychological health conditions can be grouped under physical, emotional, behavioral and cognitive symptoms ${ }^{22}$.

To identify occupational psychological health conditions among the construction professionals and construction trade workers, four major constructs of psychological indicators namely: individual lifestyle, psychosocial symptoms, physiological conditions, and work attitudes were assessed. These four major constructs were further broken down into twenty (20) indicators to assess whether the research participants were experiencing some form of occupational psychological health conditions. These measures used to identify occupational psychological health conditions among the research participants as shown in Table 1, were adopted from occupational safety and health report written by Hassard and $\operatorname{Cox}^{20}$ and modified for this study.

\section{Questionnaire design}

This research aimed at identifying occupational psychological health conditions among the participants based on the responses provided. Closed-ended questions were suitable for the quantitative nature of the survey questionnaire. A total of 20 research questions were developed to suit the 20 measures adopted by this study. A Likert scale ranging from 1 to 6 was used to determine the level of frequency of the measures in the questionnaire. For positive questions such as how often do you engage in some form of exercise?, the following frequency qualifications were used 'Very frequently (that is, more than 2 times a day) rated as 6 points, 'Frequently (that is, 1 to 2 times a day)' rated as 5 points, 'Occasionally (that is, 2 to 3 times a week)' rated as 4 points, 'Rarely (that is, 2 to 3 times a month)' rated as 3 points, 'Very rarely (that is, once a month or less)' rated as 2 points and 'Not at all' rated as 1 point.

On the other hand, for negative questions such as how

Table 1. Measures of occupational psychological health conditions.

\begin{tabular}{|l|l|}
\hline \multicolumn{1}{|c|}{ Constructs } & \multicolumn{1}{c|}{ Indicators of occupational psychological health } \\
\hline Individual Lifestyle & Exercise, Eating habit, Weight management, Alcohol intake, Use of drugs or pills, Sleep pattern and Changes in behavior. \\
\hline Psychosocial Symptoms & Stress, Depression, Anxiety, Resilience, Harassment / Violent and Abusiveness. \\
\hline Physiological Conditions & Cardiovascular diseases, Musculoskeletal disorders, General health and Medical history. \\
\hline Work Attitudes & Work happiness, Job commitment, and Advocacy. \\
\hline
\end{tabular}

Source: Hassard and $\mathrm{Cox}^{20}$ in Occupational Safety and Health Report. 
frequently do you drink alcohol?, the following frequency qualifications were used, 'Not at all' rated as 6 points, 'Very rarely (that is, once a month or less)' rated as 5 points, 'Rarely (that is, 2 to 3 times a month)' rated as 4 points, 'Occasionally (that is, 2 to 3 times a week)' rated as 3 points, 'Frequently (that is, 1 to 2 times a day)' rated as 2 points and 'Very frequently (that is, more than 2 times a day) rated as 1 point. Using these scales, lower mean scores obtained by a group depict the participants are more prevalent in adverse psychological health conditions than the other group. The questionnaire was written solely in English as all the research participants had some level of education and could understand English.

A pilot study was conducted with 15 construction employees with more than 10 years of working experience, to test the appropriateness of the questionnaires by reviewing it. This initial exercise resulted in a modified final questionnaire with appropriate content validity.

\section{Hypothesis Testing Approach}

The Test statistics for this study was stated, and this was used as the basis for deciding whether the null hypothesis should be rejected or not. The value of the test statistics was 0.05 .

The null hypothesis, $\left(\mathrm{H}_{0}\right)$, assumed there is no statistically significant difference between the mean scores obtained from construction professionals "a" and construction trade workers " $b$ " for all indicators measured.

The alternative hypothesis, $\left(\mathrm{H}_{1}\right)$, assumed there is/ are a statistically significant difference between the mean scores obtained from construction professionals "a" and construction trade workers " $b$ " for all indicators measured.

If the $p$-value $\leq 0.05$, this indicates the difference in the mean scores is statistically significant, and hence the null hypothesis will be rejected, and the alternative hypothesis considered.

If the $p$-value $\geq 0.05$, the null hypothesis will not be rejected.

\section{Data Analysis}

The responses provided by the participants were used to determine whether a participant based on a measure was experiencing adverse occupational psychological health condition. Using the Statistical Package for Social Scientists (SPSS) version 19, the data obtained was subjected to quantitative analysis. The data were analyzed using both descriptive and inferential statistics. Descriptive statistical forms of mean and standard deviation were used to describe the central location of the frequency distribution and to indicate how the results of the data have been spread out respectively. Blom's fractional rank estimation method was used to determine whether the data obtained from the two construction working groups were normally distributed for all the variables measured before their scores could be compared.

The inferential statistical form of independent twosample T-test analysis was used to compare the mean scores obtained from the two construction working groups. Levene's test for equality of variances was used for this test, to determine whether the differences between the mean scores were statistically significant. From the Levene's test, the $F$ values and Significant or $P$ values obtained for each indicator measured have been presented.

The Cronbach alpha values were used to determine whether the various indicators grouped under each of the four constructs were internally consistent and reliable. Reliability or inter-item consistency is considered unacceptable unless the Cronbach alpha value of the construct is 0.7 or above ${ }^{35}$. To increase the reliability of a construct, the Cronbach alpha values of each item if deleted from the construct should be known and variables with lower alpha values removed ${ }^{16,32}$. The Cronbach alpha values of each of the four constructs and their various indicators have also been presented.

\section{Results}

The background information of the research participants has been shown in Table 2 .

The results of the data collected from 150 construction professionals and 150 construction trade workers in Ghana have been presented in Table 3. Values marked with (a) represent scores from the construction professionals' group and values marked with (b) represent scores from the construction trade workers' group.

Blom's fractional rank estimation test revealed the data were normally distributed and hence the results of the two groups could be compared for all the variables ${ }^{35}$. Using Levene's test for equality of variances employed under independent two-sample T-test, the test statistics value of 0.05 was adopted. This value was used to determine whether the difference between the mean scores obtained from the two construction groups was statistically significant. Values that indicate a statistically significant difference between the mean scores of the two construction working groups are marked with $\left(^{*}\right)$.

\section{Discussion}

The results from the data analysis as presented in Table 3 depict that the mean scores obtained by the construction trade workers were different from the mean scores obtained by the construction professionals for all indicators measured. These results indicate that the construction trade workers were found to be more prevalent in adverse occupational psychological health conditions than the construction professionals. The p-value of most of the 
Table 2. Background information of Research Participants.

\begin{tabular}{|c|c|c|c|}
\hline \multirow{2}{*}{ Information } & \multirow{2}{*}{ Categories } & \multicolumn{2}{|c|}{ Percentage (150 Participants each) } \\
\hline & & Construction Professionals group & Construction Trade workers group \\
\hline \multirow[t]{4}{*}{ Age } & $25-35$ & $27 \%$ & $20 \%$ \\
\hline & $36-45$ & $40 \%$ & $40 \%$ \\
\hline & $46-55$ & $20 \%$ & $29 \%$ \\
\hline & $>55$ & $13 \%$ & $11 \%$ \\
\hline Years of & Less than 1 year & $7 \%$ & $4 \%$ \\
\hline working & $1-5 y r s$ & $42 \%$ & $24 \%$ \\
\hline \multirow[t]{2}{*}{ experience } & $6-10 y r s$ & $31 \%$ & $60 \%$ \\
\hline & Above $10 y r s$ & $20 \%$ & $11 \%$ \\
\hline Level of & Ghana Certificate Exams "A" level & $2 \%$ & $4 \%$ \\
\hline \multirow[t]{5}{*}{ Education } & Ghana Certificate Exams "O" level & $0 \%$ & $2 \%$ \\
\hline & Junior High School level & $2 \%$ & $38 \%$ \\
\hline & Secondary School level & $4 \%$ & $9 \%$ \\
\hline & Technical or Vocational level & $40 \%$ & $40 \%$ \\
\hline & Graduate level or Above & $51 \%$ & $7 \%$ \\
\hline \multirow[t]{2}{*}{ Marital Status } & Married & $80 \%$ & $71 \%$ \\
\hline & Single & $20 \%$ & $29 \%$ \\
\hline \multirow[t]{2}{*}{ Gender } & Male & $87 \%$ & $96 \%$ \\
\hline & Female & $13 \%$ & $4 \%$ \\
\hline
\end{tabular}

Table 3. Results of the psychological health indicators among construction professionals ${ }^{(a)}$ and construction trade workers ${ }^{(b)}$.

\begin{tabular}{|c|c|c|c|c|c|c|}
\hline \multirow{2}{*}{ No. } & \multirow{2}{*}{ Indicators } & \multirow{2}{*}{ Groups Mean } & \multirow{2}{*}{$\begin{array}{c}\text { Groups Standard } \\
\text { deviation }\end{array}$} & \multicolumn{2}{|c|}{ Levene's test for equality of variance } & \multirow{2}{*}{ Cronbach Alpha values } \\
\hline & & & & F- value & P-value & \\
\hline \multicolumn{5}{|c|}{ Construct 1: Individual Lifestyle } & & 0.837 \\
\hline 1 & Exercise & $4.16^{\mathrm{a}}, 4.01^{\mathrm{b}}$ & $1.316^{\mathrm{a}}, 1.378^{\mathrm{b}}$ & 6.299 & $0.013 *$ & 0.878 \\
\hline 2 & Eating Habit & $4.33^{a}, 3.66^{b}$ & $1.224^{\mathrm{a}}, 1.442^{\mathrm{b}}$ & 67.893 & $0.000 *$ & 0.794 \\
\hline 3 & Weight Management & $4.12^{\mathrm{a}}, 3.91^{\mathrm{b}}$ & $1.331^{\mathrm{a}}, 1.406^{\mathrm{b}}$ & 9.906 & $0.002 *$ & 0.791 \\
\hline 4 & Alcohol Intake & $4.41^{\mathrm{a}}, 4.05^{\mathrm{b}}$ & $1.176^{\mathrm{a}}, 1.368^{\mathrm{b}}$ & 26.678 & $0.000 *$ & 0.822 \\
\hline 5 & Use of Drugs or Pills & $3.66^{a}, 3.49^{b}$ & $1.442^{\mathrm{a}}, 1.446^{\mathrm{b}}$ & 0.200 & 0.655 & 0.787 \\
\hline 6 & Sleep Pattern & $3.49^{a}, 3.29^{b}$ & $1.304^{\mathrm{a}}, 1.411^{\mathrm{b}}$ & 0.882 & 0.348 & 0.821 \\
\hline 7 & Changes in Behaviour & $3.92^{\mathrm{a}}, 3.61^{\mathrm{b}}$ & $1.293^{a}, 1.442^{b}$ & 12.682 & $0.000 *$ & 0.796 \\
\hline \multicolumn{5}{|c|}{ Construct 2: Psychosocial symptoms } & & 0.846 \\
\hline 8 & Stress & $3.06^{\mathrm{a}}, 2.98^{\mathrm{b}}$ & $1.183^{a}, 1.303^{b}$ & 0.243 & 0.622 & 0.826 \\
\hline 9 & Depression & $3.45^{\mathrm{a}}, 3.22^{\mathrm{b}}$ & $1.319^{a}, 1.399^{b}$ & 0.833 & 0.362 & 0.821 \\
\hline 10 & Anxiety & $3.05^{a}, 3.03^{b}$ & $1.353^{\mathrm{a}}, 1.195^{\mathrm{b}}$ & 0.557 & 0.456 & 0.821 \\
\hline 11 & Resilience & $3.76^{a}, 3.43^{b}$ & $1.432^{\mathrm{a}}, 1.440^{\mathrm{b}}$ & 0.793 & 0.374 & 0.801 \\
\hline 12 & Harassment / Violent & $4.36^{\mathrm{a}}, 3.76^{\mathrm{b}}$ & $1.082^{\mathrm{a}}, 1.432^{\mathrm{b}}$ & 5.168 & $0.024 *$ & 0.824 \\
\hline 13 & Abusiveness & $4.23^{\mathrm{a}}, 3.91^{\mathrm{b}}$ & $1.282^{\mathrm{a}}, 1.406^{\mathrm{b}}$ & 7.171 & $0.008^{*}$ & 0.828 \\
\hline \multicolumn{5}{|c|}{ Construct 3: Physiological conditions } & & 0.713 \\
\hline 14 & Cardiovascular diseases & $4.43^{\mathrm{a}}, 4.16^{\mathrm{b}}$ & $1.095^{\mathrm{a}}, 1.316^{\mathrm{b}}$ & 42.675 & $0.000 *$ & 0.776 \\
\hline 15 & Musculoskeletal disorders & $3.76^{a}, 2.93^{b}$ & $1.432^{\mathrm{a}}, 1.299^{\mathrm{b}}$ & 24.623 & $0.000 *$ & 0.592 \\
\hline 16 & General Health & $3.42^{\mathrm{a}}, 3.05^{\mathrm{b}}$ & $1.439^{a}, 1.353^{b}$ & 1.873 & 0.172 & 0.533 \\
\hline 17 & Medical History & $3.51^{\mathrm{a}}, 3.31^{\mathrm{b}}$ & $1.446^{\mathrm{a}}, 1.205^{\mathrm{b}}$ & 2.608 & 0.107 & 0.649 \\
\hline \multicolumn{3}{|c|}{ Construct 4: Work attitudes } & & & & 0.714 \\
\hline 18 & Work happiness & $4.01^{a}, 3.73^{b}$ & $1.378^{\mathrm{a}}, 1.436^{\mathrm{b}}$ & 15.57 & $0.000^{*}$ & 0.479 \\
\hline 19 & Job commitment & $4.23^{\mathrm{a}}, 4.12^{\mathrm{b}}$ & $1.282^{\mathrm{a}}, 1.331^{\mathrm{b}}$ & 2.487 & 0.116 & 0.602 \\
\hline 20 & Advocacy & $4.53^{a}, 3.33^{b}$ & $1.085^{a}, 1.427^{b}$ & 139.972 & $0.000^{*}$ & 0.764 \\
\hline
\end{tabular}

indicators measured were less than 0.05 as shown in Table 3 , the null hypothesis will therefore be rejected, and the alternative hypothesis considered for those indicators. The psychological health indicators that revealed statistically significant differences between the two construction groups were: exercise, eating habit, weight management, alcohol intake, changes in behavior, harassment/violent, abusiveness, cardiovascular, musculoskeletal, work happiness and advocacy. The differences in the outcome of the results of the construction professionals and construction 
trade workers could be due to the differences in these characteristics: individual personality, age, marital status, gender, level of education, years of working experience, task level, role demands, and income level 17,4,7,12.

On the other hand, indicators such as the use of drugs/ pills, sleep pattern, stress, anxiety, depression, resilience, general health, medical history, and commitment, had their $\mathrm{p}$-values greater than 0.05 . These results indicate that the differences in the mean scores of the two groups were not statistically significant; hence the null hypothesis will not be rejected for these other indicators. The similarities in the mean scores obtained from the construction professionals and construction trade workers indicate that these psychological indicators can affect any person regardless of their differences in various aspects ${ }^{2,36}$. It has been revealed by previous studies that about 450 million persons worldwide suffer from psychological conditions such as stress, depression, and anxiety disorders, which has led to various forms of disability and ill-health globally ${ }^{37}$. The World Health report in 2001 also indicated that one in four persons in the world would be affected by psychological disorders at some point in their lives. Psychological issues should, therefore, be taken much seriously.

The internal consistency and reliability test using the Cronbach alpha values indicate that the inter-item consistency of all the four constructs was good, as the Cronbach alpha values for the constructs as shown in Table 3 ranges from 0.837 to 0.713 . The detailed descriptions of the results of the indicators have been provided under their main constructs.

\section{Construct 1: Individual Lifestyle}

Many studies have linked psychological well-being and ill-being conditions to individual lifestyle ${ }^{17,20}$. Lifestyle as a major construct of occupational psychological health conditions among construction employees in Ghana was analyzed based on seven indicators, namely; exercise, eating habits, weight management, alcohol intake, use of drugs or pills, sleep pattern and changes in behavior. Based on the responses to the questions for these indicators under lifestyle, the construction trade workers were found to be more prevalent in the adverse occupational psychological health conditions than the construction professionals. Tight deadline pressures and limited time for relaxation associated with construction work, could expose construction trade workers to poor lifestyle choices such as poor eating habits and lack of sleep ${ }^{14,17,19}$.

Lifestyle choices can be directly linked with symptoms of anxiety, depression, Attention deficit hyperactivity disorder (ADHD), and more ${ }^{38}$. The lifestyle of an individual could, therefore, have a profound impact on their mental health. Even though the mean scores differ, it could be stated that based on the lifestyle measures, both construction professionals and construction trade workers were likely to experience some form of occupational psychological health conditions. The consequences of a poor lifestyle of construction employees could have both direct and indirect cost such as errors in decision making and violence at the construction workplace ${ }^{39,40}$. All construction employees are encouraged to adopt a positive lifestyle to improve their quality of life. Positive lifestyle choices such as regular exercise, healthy eating habits, and good sleeping patterns improve psychological conditions by reducing negative moods, anxiety, and depression, as well as improve cognitive functions and self-esteem ${ }^{41,20}$.

\section{Construct 2: Psychosocial symptoms}

Psychosocial symptoms as a major construct of occupational psychological health conditions among construction employees in Ghana were analyzed based on six indicators, namely; stress, depression, anxiety, resilience, harassment or violent and abusiveness. The results indicate that each construction group had their participants experiencing some form of adverse occupational psychological health conditions. The dynamic, complex and uncertain nature of the construction industry could expose both construction professionals and construction trade workers to various forms of psychosocial conditions ${ }^{4,6}$.

The findings of the study are in conformity with the study by Dzirasah ${ }^{42}$ revealing that about 60 to 70 percent of organizations visited in Ghana, had their workers having some form of psychological health problems with stress as the common one. Though some researchers have argued that there are benefits associated with some amount of psychosocial conditions such as feelings of pressure, stress and workaholism ${ }^{5,2}$; these adverse occupational psychological conditions could have consequences undoubtedly on the ability of construction employees to carry out their construction works efficiently ${ }^{1}$; with other implications on the construction industry such as increased injury/accident rates and errors in decision making ${ }^{7,11,12}$. Emotional symptoms such as rage, discouragement and mood swings are commonly reported, and these are associated with the psychosocial conditions of stress, anxiety, depression, harassment and abuse $\mathrm{e}^{3,43}$. Emotional problems are seen as the primary indicators of psychosocial conditions ${ }^{44}$. Other symptoms include the feeling of being overwhelmed, irritability, mood swings, agitation, feeling tensed, inability to relax, frustration, depression, isolation, sense of loneliness, resentment, anger and substance abuse $^{22,45}$. Stress and other psychological ill-being conditions are gradually becoming the primary source of mortality among employees ${ }^{38}$.

\section{Construct 3: Physiological conditions}

Physiological conditions as a major construct of 
occupational psychological health conditions among construction employees in Ghana was analyzed based on four indicators, namely; cardiovascular diseases, musculoskeletal disorders, general health, and medical history. The results also indicate that the construction trade workers when assessed on the basis of physiological health were more prevalent in the adverse occupational psychological health conditions than the construction professionals. The outcome of these results could be due to factors such as differences in task levels; as high levels of tasks associated with construction trade workers' job could expose them to physiological conditions ${ }^{12,19}$.

Employees' physiological problems such as fatigue, headaches, insomnia, and gastrointestinal disturbances are usually reported, and these have been linked with psychological ill-being conditions such as burnout ${ }^{11,46}$. Similar to the findings, previous researchers also revealed that the employees' psychological ill-being conditions can be manifested in the physical health of the person, with the person experiencing symptoms such as: chronic fatigue, chest pain, rapid heartbeats, aches or pains, weakness, nausea, dizziness, diarrhoea or constipation, weight gain or loss, breathlessness, frequent colds, loss of sex drive, sweaty palms, hyperactivity, muscular tension, tiredness, jaw clenching or teeth grinding ${ }^{32,16}$.

\section{Construct 4: Work attitudes}

Work attitude as a major construct of occupational psychological health conditions among construction employees in Ghana was analyzed based on three indicators, namely: work happiness, job commitment, and advocacy. Based on the responses to the questions on the various indicators under work attitudes, the construction trade workers were more in the adverse occupational psychological health conditions than the construction professionals. The result could be due to the fact that construction trade workers are usually placed at the lowest rank of the construction industry and are usually paid lesser than the construction professionals. The imbalance between construction trade workers efforts and the rewards received could trigger poor work attitudes ${ }^{12}$.

Work attitudes of employees have been proven to have a direct relationship with their occupational psychological health ${ }^{17}$. Employees who are happy, committed and advocate are intrinsically driven to work hard and are likely to enjoy their work ${ }^{3,47}$. Poor work attitude could have a significant relationship with various employees' emotional psychological ill-being conditions including low self-esteem, depression, anxiety, feelings of helplessness and irritability ${ }^{44}$. Employees who have poor work attitudes could be vulnerable to the adverse psychological health condition of emotional exhaustion, which is described as the depletion of emotional resources ${ }^{46}$. Emotional exhaustion can also be described as a feeling of being emotionally overextended and exhausted by one's work ${ }^{43}$. The negative emotions of emotional exhaustion can make employees feel very uncomfortable, which can negatively affect their job performance at the workplace ${ }^{48}$.

The mental scope and functionality of the employees with poor work attitudes can also be affected in various ways when cognitive psychological ill-being is present, with indicators such as the inability to concentrate, memory problems, seeing only the pessimistic, poor judgment, constant worry, anxiety, loss of objectivity and fearful anticipation ${ }^{49,50}$. Positive thoughts patterns are also associated with employees with positive work attitudes, and these evoke stronger emotions in employees enabling them to have greater involvement and engagement in work ${ }^{51}$. To promote more positive work attitudes of commitment and dedication in construction trade workers, it is essential for stakeholders to pay attention to their happiness, to make them feel valued, cared for and appreciated for their work efforts $^{2}$. The average happiness index calculated globally in the year 2018 was 5.39 out of 10 points. Ghana as a country, for instance, achieved a happy index score of 4.66 and ranked 106th of all the countries analyzed globally ${ }^{52}$. There is the need to promote work factors that lead to positive attitudes of work happiness, job commitment and advocacy among all construction employees in Ghana and globally.

\section{Conclusion and Recommendation}

Previous studies have shown that occupational psychological disorders such as stress, depression, and anxiety, have adverse consequences on various aspects of the employee's life as well as the company. This study sort to explore psychological health indicators among construction employees. To achieve this aim, a target of 300 questionnaires was equally distributed to construction professionals and construction trade workers in Ghana. Quantitative analysis was done, and a comparison of the results made, to determine which of the two construction working groups was more prevalent in adverse occupational psychological health conditions.

Four main constructs of psychological health indicators namely: individual lifestyle, psychosocial symptoms, physiological conditions, and work attitudes, were further divided into twenty (20) occupational psychological health indicators. The measures adopted for the study were based on the review of related literature works in occupational psychology. The previous studies indicate that adverse occupational psychological health conditions are directly related to poor individual lifestyle choices (in terms of exercise, eating habits, sleeping patterns and the likes) as well as physiological conditions, psychosocial symptoms (such as stress, depression, anxiety) and poor work 
attitudes (in terms of work happiness, job commitment and advocacy). The responses provided by the participants on how they relate to these indicators, using a 1-6 Likert scale, were used to assess whether a participant was experiencing adverse occupational psychological health conditions.

The findings from the study imply that there is the existence of some form of occupational psychological health conditions among both the construction professionals and construction trade workers. The results further revealed that using the measures of individual lifestyle and work attitudes, there were statistically significant differences between the mean scores obtained from the two construction working groups. The results using the measure of psychosocial symptoms and physiological conditions, however revealed that, there were no much statistically significant differences between the mean scores of the two construction working groups. This particular outcome from the study confirms the statement by the World Health Organization that one (1) in four (4) persons in the world suffers from some form of psychological health disorders.

The overall results indicate that the construction trade workers were found to be more prevalent in the adverse occupational psychological health conditions; as their mean scores were lower than the mean scores of the construction professionals. The outcome of the results could be due to underlining differences among the two construction groups in terms of various characteristics such as individual personality, age, marital status, gender, level of education, years of working experience, task level, role demands, and income levels. For instance, the level of education of the construction professionals was higher than the construction trade workers. On the other hand, factors such as task level and role demand of the construction trade workers were also higher than the construction professionals. These factors could significantly lead to differences in the level of vulnerability to adverse occupational psychological health conditions.

Construction employees are to take full responsibility of maintaining their psychological well-being by ensuring that they are in good physical health, sleeping well, eating well, exercising, and avoiding harmful alcohol and other drugs. These are things that are fundamental to the wellbeing of all people but of greater importance to people more prone to psychological ill-being conditions. Good sleep patterns are particularly important for employees' well-being, as sleep disorders are often one of the first signs of experiencing adverse psychological health conditions. Human resource managers, health and safety officers and labour unions should help increase psychological health awareness to encourage construction employees to take their psychological health more seriously.
Stakeholders of the construction industry should also pay critical attention to the well-being of their employees both physically and psychologically. This study recommends psychological interventions for all employees in the construction industry such as the establishment of welfare committee and provision of occupational psychological support systems (for example: offering free counseling services and paying medical bills for employees). Factors leading to employees' psychological well-being conditions should be promoted for the individual and organizational benefits. These will enhance the well-being of all construction employees and promote a psychologically safe and healthy construction workplace. This research study forms part of the basic steps in developing a preventive psychological health management model for all construction employees. This model will ensure that the physical, mental and social well-being of both construction professionals and construction trade workers are enhanced and their job performance and productivity levels optimized. The findings from this study will, therefore, add to the body of knowledge on occupational psychology in the construction industry.

\section{Data Availability Statement}

All data generated or analyzed during the study are included in this article and are available from the corresponding author by request.

\section{Acknowledgment}

This research work is fully sponsored by the Hong Kong PhD Fellowship Scheme of the Research Grants Council.

\section{References}

1. Campbell WK, Bonacci AM, Shelton J, et al. "Psychological Entitlement: Interpersonal Consequences and Validation of a Self-Report Measure". Journal of Personality Assessment. 2004; 83(1): 29-45.

2. Landy FJ, Conte JM. "Work in the $21^{\text {st }}$ Century: An introduction to industrial and organizational psychology", $5^{\text {th }}$ edition, Wiley: American Psychological Association. 2016. ISBN-13: 9781118976272.

3. O’Donoghue A, Conway E, Bosak J. "Abusive supervision, employee well-being and ill-being: the moderating role of core self-evaluations". Emotions and Organizational Governance. Research on Emotion in Organizations. 2016; 12(1): 3 -34.

4. Bowen P, Edwards P, Lingard $\mathrm{H}$, et al. "Predictive modelling of workplace stress among construction professionals". Journal of Construction Engineering and Management. 2014b; 140(3): 1-10.

5. Russell JA. "Core affect and the psychological construction of emotion". Psychological Review.2003; 110(1): 145-172.

6. Chan IYS, Leung MY, Liu AMM. "Occupational health management system: A study of expatriate construction professionals". Accident Analysis and Prevention. 2016; 93(1): 280-290.

7. Leung MY, Liang Q, Olomolaiye P. "Impact of job stressors and stress on the safety behaviour and accidents of construction workers". Journal of Management in Engineering. 2016; 32(1): 1-10.

8. Langford D, Rowlinson S, Sawacha E. "Safety behaviour and safety management: Its influence on the attitudes of workers in the UK 
construction industry". Engineering Construction and Architectural Management. 2000; 7(2): 133-140.

9. Adei D, Kunfaa EY. "Occupational Health and Safety Policy in the Operations of the Wood Processing Industry in Kumasi, Ghana". Journal of Science and Technology. 2007; 27(2): 159-169.

10. Lazarus RS, DeLongis A, Folkman S, et al. "Stress and adaptation outcomes: The problem of confounded measures". American Psychologist. 1985; 40(1): 770-779.

11. Chan IYS, Leung MY, Yu SSW. "Managing the stress of Hong Kong expatriate construction professionals in Mainland China: Focus group study exploring individual coping strategies and organizational support." Journal of Construction Engineering and Management. 2012; 138(10): 1150-1160.

12. Leung MY, Chan IYS. "Exploring stressors of Hong Kong expatriate construction professionals in Mainland China: Focus Group Study". Journal of construction Engineering and Management. 2012; 138(1): 78-88.

13. Bowen P, Edwards $\mathrm{P}$, Lingard $\mathrm{H}$, et al. "Predictive modelling of workplace stress among construction professionals". Journal of Construction Engineering and Management. 2014; 140(3): 1-10.

14. Chartered Institute of Building (CIOB). "Occupational stress in the construction industry: CIOB published national stress survey results." 2006. http://www.ciob.org.uk/resources/publications. (accessed on 19/12/2018)

15. Health and Safety Executive. "An analysis of the prevalence and distribution of stress in the construction industry". Rep. No. RR518, Health and Safety Laboratory, Derbyshire, U. K. 2007. http://www. hse.gov.uk/research/rrpdf/rr518.pdf. (accessed on 11/12/2018).

16. Enshassi A, Swaity E, Arian F. "Investigating common causes of burnout in the construction industry". International Journal of Construction Project Management. 2016; 8(1): 43-56.

17. Quick JC, Wright TA, Adkins JA, et al. "Preventive stress management in organizations", 2nd edition, American Psychological Association. 2013; ISBN-13: 978-1433811852.

18. Leung MY, Chan IY, Yu J. "Preventing construction worker injury incidents through the management of personal stress and organizational stressors". Accident Analysis and Prevention. 2012; 48(1): 156-166.

19. Leung MY, Liang Q, Chan IYS. "Development of a stressorsstress-performance-outcome model for Expatriate construction professionals". Journal of Construction Engineering and Management. 2017; 143(5): 1-11.

20. Hassard J, Cox T. Occupational Safety and Health Wikipedia contributors. "Mental health at work". 2016. https://oshwiki.eu/ index.php?title=Mental_health_at_work\&oldid=245971. $\quad$ (accessed 01/12/ 2018)

21. Kivimäki M, Vahtera J, Elovainio M, et al. "Optimism and pessimism as predictors of change in health after death or onset of severe illness in family". Health Psychology. 2005; 24 (4): 413- 421.

22. Ademola A. "Performance under stress: What the coaches should do". A paper delivered at the seminar on mental skill training in sport organized by National Institute for Sport, Lagos. 2005.

23. Richman JA, Rospenda KM, Flaherty JA, et al. "Workplace harassment, active coping, and alcohol-related outcomes". Journal of Substance Abuse. 2001; 13(3): 347-366.

24. Ryan RM, Deci EL. "On Happiness and Human Potentials: A Review of Research on Hedonic and Eudaimonic Well-Being". Annual Review of Psychology. 2001; 52(1): 141-166.

25. Wrzesniewski A, Dutton JE, Debebe G. "Interpersonal sense making and the meaning of work". Research in Organizational Behavior. 2003; 25(1): 93-135.
26. Dragano N, Verde PE, Siegrist J. "Organisational downsizing and work stress: Testing synergistic health effects in employed men and women". Journal Epidemiol Community Health. 2005; 59(8): 694-699.

27. American Psychiatric Association, "Diagnostic and statistical manual of mental disorders (DSM-5®)". American Psychiatric Publication. 2013.

28. Tran TD, Tran T, Fisher J. "Validation of the depression anxiety stress scales (DASS) 21 as a screening instrument for depression and anxiety in a rural community-based cohort of northern Vietnamese women. BioMed Central Psychiatry. 2013; 13(24): 1-7.

29. Greenberg JS. "Comprehensive Stress Management" (3 ${ }^{\text {rd }}$ edition). Dubuque, IA: Wm. C. Brown Publishers. 1990.

30. Lazarus RS, Folkman S. "Stress, appraisal, and coping". New York: Springer. 1984

31. Mehta RS, Chaudhary RN. "Job related stress among the nurses working in critical care areas at BPKIHS, Nepal". Nursing and Midwifery Research Journal. 2005; 1(2): 70-76.

32. Magotra I. "Tracing stress symptoms: an empirical study of manufacturing industry". Journal of Human Resource Management. 2016; 16(2): 44-55.

33. World Health Organization "Mental health policies and programmes in the workplace". Mental health policy and service guidance package, Geneva. 2005. whqlibdoc.who.int/publications/2005/9241546794_ eng.pd. (accessed on 12/12/2018).

34. Pennonen M. "Recovery from work stress. Antecedents, processes and Outcomes". School of Social Sciences and Humanities, University of Tampere. 2011. http://docplayer.net/29943252-Recovery-fromwork-stress.html. (accessed on 12/12/2018).

35. Lo R. "Advanced Quantitative Methods, APSS6003". Unpublished material: Lecture notes. Hong Kong Polythetic University. 2018.

36. Ashleigh M, Mansi A. "The psychology of people in organizations". Pearson 1st edition. 2012.

37. Majidi M, Khadembashi N, Etemad K, et al. Associated factors with major depression: a path analysis on NHANES 2013-2014 study. International Journal of Culture and Mental Health. 2019; 11(4): 1-11.

38. Elbe AM, Lyhne SN, Madsen EE, et al. "Is regular physical activity a key to mental health? Commentary on "Association between physical exercise and mental health in 1.2 million individuals in the USA between 2011 and 2015: A cross-sectional study", by Chekroud et al., published in Lancet Psychiatry. Journal of Sport and Health Science. 2019; 8(1): 6-7.

39. Dodoo JE, Al-Samarraie H. "Factors leading to unsafe behavior in the twenty first century workplace: a review". Management Review Quarterly. 2019; 136(10): 1-24.

40. Di-Martino V. "Relationship between work stress and workplace violence in the health sector". International Labour Office, International Council of Nurses, World Health Organization, Geneva. 2003. http://www.who.int/violence_injury_prevention/violence/ interpersonal/en/WVstresspaper.pdf. (accessed on 23/12/2018).

41. Knapen J, Vancampfort D, Moriën Y, et al. "Exercise therapy improves both mental and physical health in patients with major depression". Disability and rehabilitation. 2015; 37(16): 1490-1495.

42. Dzirasah K. "Let us Escape Stress Related Problems". Ghana newspaper agency. 2005. http://www.ghananewsagency.org. (accessed on 18/12/2018).

43. Ashkanasy NM, Dorris AD. "Emotions in the workplace". Annual Review of Organizational Psychology and Organizational Behavior. 2017; 4(1): 67-90.

44. Jones SK, Griep Y. "I Can Only Work So Hard Before I Burn Out: A Time Sensitive Conceptual Integration of Ideological Psychological 
Contract Breach, Work Effort, and Burnout". Frontiers in psychology 2018; 9(131): 1-14.

45. Grob GN. "Mental illness and American society". 2019; 1875-1940: (Vol. 5316). Princeton University Press.

46. Bakker AB, Demerouti E. "Job demands-resources theory: Taking stock and looking forward". Journal of Occupational Health Psychology. 2017; 22(3): 273-285.

47. Miao C, Humphrey RH, Qian S. "A meta-analysis of emotional intelligence and work attitudes". Journal of Occupational and Organizational Psychology. 2017; 90(2): 177-202.

48. Devery H, Scanlan JN, Ross J. "Factors associated with professional identity, job satisfaction and burnout for occupational therapists working in eating disorders: A mixed methods study". Australian Occupational Therapy Journal. 2018; 65(6): 523-532.
49. Balzarotti S, Biassoni F, Villani D, et al. "Individual differences in cognitive emotion regulation: Implications for subjective and psychological well-being". Journal of Happiness Studies. 2016; 17(1): 125-143.

50. Puolakanaho A, Tolvanen A, Kinnunen SM, et al. "Burnout-related illbeing at work: Associations between mindfulness and acceptance skills, worksite factors, and experienced well-being in life". Journal of Contextual Behavioral Science. 2018; 10(1): 92-102.

51. Wesarat PO, Sharif MY, Majid AHA. "A conceptual framework of happiness at the workplace". Asian Social Science. 2015; 11(2): 78-88.

52. World Happiness Report Happiness index - Country rankings: Economic indicators for over 200 countries". 2018. "https:// www.theglobaleconomy.com/rankings/happiness/ (accessed on 14/01/2019). 


\section{Supplementary material (Research Questionnaire)}

Table A. Research questionnaire designed for respondents in Ghana.

\begin{tabular}{|c|c|c|c|c|c|c|c|}
\hline \multirow{2}{*}{ No. } & \multirow{2}{*}{ Research Questions } & \multicolumn{6}{|c|}{ Likert Scale Point } \\
\hline & & 1 & 2 & 3 & 4 & 5 & 6 \\
\hline 1 & $\begin{array}{l}\text { How often do you engage } \\
\text { in some form of exercise? }\end{array}$ & Not at all & $\begin{array}{l}\text { Very rarely ( } 1 \text { in a } \\
\text { month or less) }\end{array}$ & $\begin{array}{c}\text { Rarely (2-3 } \\
\text { times a month) }\end{array}$ & $\begin{array}{l}\text { Occasionally } \\
\text { (2-3 times a } \\
\text { week) }\end{array}$ & $\begin{array}{c}\text { Frequently (1-2 } \\
\text { times a day) }\end{array}$ & $\begin{array}{l}\text { Very frequently } \\
\text { (>2times a day) }\end{array}$ \\
\hline 2 & $\begin{array}{l}\text { How frequently do you } \\
\text { eat healthy balanced } \\
\text { nutrition? }\end{array}$ & Not at all & $\begin{array}{l}\text { Very rarely ( } 1 \text { in a } \\
\text { month or less) }\end{array}$ & $\begin{array}{c}\text { Rarely (2-3 } \\
\text { times a month) }\end{array}$ & $\begin{array}{l}\text { Occasionally } \\
\text { (2-3 times a } \\
\text { week) }\end{array}$ & $\begin{array}{c}\text { Frequently (1-2 } \\
\text { times a day) }\end{array}$ & $\begin{array}{l}\text { Very frequently } \\
\text { (>2times a day) }\end{array}$ \\
\hline 3 & $\begin{array}{l}\text { How often do you ensure } \\
\text { your body mass index is } \\
\text { within the normal range? }\end{array}$ & Not at all & $\begin{array}{l}\text { Very rarely (1 in a } \\
\text { month or less) }\end{array}$ & $\begin{array}{c}\text { Rarely (2-3 } \\
\text { times a month) }\end{array}$ & $\begin{array}{l}\text { Occasionally } \\
\text { (2-3 times a } \\
\text { week) }\end{array}$ & $\begin{array}{c}\text { Frequently (1-2 } \\
\text { times a day) }\end{array}$ & $\begin{array}{l}\text { Very frequently } \\
\text { (>2times a day) }\end{array}$ \\
\hline 4 & $\begin{array}{l}\text { How frequently do you } \\
\text { drink alcohol? }\end{array}$ & $\begin{array}{l}\text { Very frequently } \\
\text { (>2times a day) }\end{array}$ & $\begin{array}{l}\text { Frequently (1-2 } \\
\text { times a day) }\end{array}$ & $\begin{array}{l}\text { Occasionally } \\
\text { (2-3 times a } \\
\text { week) }\end{array}$ & $\begin{array}{c}\text { Rarely (2-3 } \\
\text { times a month) }\end{array}$ & $\begin{array}{l}\text { Very rarely ( } 1 \text { in } \\
\text { a month or less) }\end{array}$ & Not at all \\
\hline 5 & $\begin{array}{l}\text { How often do you take } \\
\text { any drug or pill to make } \\
\text { you feel relaxed? }\end{array}$ & $\begin{array}{l}\text { Very frequently } \\
\text { (>2times a day) }\end{array}$ & $\begin{array}{l}\text { Frequently (1-2 } \\
\text { times a day) }\end{array}$ & $\begin{array}{l}\text { Occasionally } \\
\text { (2-3 times a } \\
\text { week) }\end{array}$ & $\begin{array}{c}\text { Rarely (2-3 } \\
\text { times a month) }\end{array}$ & $\begin{array}{l}\text { Very rarely ( } 1 \text { in } \\
\text { a month or less) }\end{array}$ & Not at all \\
\hline 6 & $\begin{array}{l}\text { How often do you have } \\
\text { enough sleep? }\end{array}$ & Not at all & $\begin{array}{l}\text { Very rarely (1 in a } \\
\text { month or less) }\end{array}$ & $\begin{array}{c}\text { Rarely (2-3 } \\
\text { times a month) }\end{array}$ & $\begin{array}{l}\text { Occasionally } \\
\text { (2-3 times a } \\
\text { week) }\end{array}$ & $\begin{array}{c}\text { Frequently (1-2 } \\
\text { times a day) }\end{array}$ & $\begin{array}{l}\text { Very frequently } \\
\text { (>2times a day) }\end{array}$ \\
\hline 7 & $\begin{array}{l}\text { How frequently do you } \\
\text { notice a dramatic change } \\
\text { in your behavior? }\end{array}$ & $\begin{array}{l}\text { Very frequently } \\
\text { (>2times a day) }\end{array}$ & $\begin{array}{l}\text { Frequently (1-2 } \\
\text { times a day) }\end{array}$ & $\begin{array}{l}\text { Occasionally } \\
\text { (2-3 times a } \\
\text { week) }\end{array}$ & $\begin{array}{c}\text { Rarely (2-3 } \\
\text { times a month) }\end{array}$ & $\begin{array}{l}\text { Very rarely ( } 1 \text { in } \\
\text { a month or less) }\end{array}$ & Not at all \\
\hline 8 & $\begin{array}{l}\text { How often do you feel } \\
\text { stressed or pressured at } \\
\text { the workplace? }\end{array}$ & $\begin{array}{l}\text { Very frequently } \\
\text { (>2times a day) }\end{array}$ & $\begin{array}{l}\text { Frequently (1-2 } \\
\text { times a day) }\end{array}$ & $\begin{array}{l}\text { Occasionally } \\
\text { (2-3 times a } \\
\text { week) }\end{array}$ & $\begin{array}{c}\text { Rarely (2-3 } \\
\text { times a month) }\end{array}$ & $\begin{array}{l}\text { Very rarely ( } 1 \text { in } \\
\text { a month or less) }\end{array}$ & Not at all \\
\hline 9 & $\begin{array}{l}\text { How often do you feel } \\
\text { depressed or unhappy? }\end{array}$ & $\begin{array}{l}\text { Very frequently } \\
\text { (>2times a day) }\end{array}$ & $\begin{array}{l}\text { Frequently (1-2 } \\
\text { times a day) }\end{array}$ & $\begin{array}{l}\text { Occasionally } \\
\text { (2-3 times a } \\
\text { week) }\end{array}$ & $\begin{array}{c}\text { Rarely (2-3 } \\
\text { times a month) }\end{array}$ & $\begin{array}{l}\text { Very rarely ( } 1 \text { in } \\
\text { a month or less) }\end{array}$ & Not at all \\
\hline 10 & $\begin{array}{l}\text { How often do you feel } \\
\text { anxious or worried? }\end{array}$ & Not at all & $\begin{array}{l}\text { Very rarely (1 in a } \\
\text { month or less) }\end{array}$ & $\begin{array}{c}\text { Rarely (2-3 } \\
\text { times a month) }\end{array}$ & $\begin{array}{l}\text { Occasionally } \\
\text { (2-3 times a } \\
\text { week) }\end{array}$ & $\begin{array}{l}\text { Frequently (1-2 } \\
\text { times a day) }\end{array}$ & $\begin{array}{l}\text { Very frequently } \\
\text { (>2times a day) }\end{array}$ \\
\hline 11 & $\begin{array}{l}\text { How frequently do you } \\
\text { adapt well to situations } \\
\text { which are problematic? }\end{array}$ & Not at all & $\begin{array}{l}\text { Very rarely ( } 1 \text { in a } \\
\text { month or less) }\end{array}$ & $\begin{array}{c}\text { Rarely (2-3 } \\
\text { times a month) }\end{array}$ & $\begin{array}{l}\text { Occasionally } \\
\text { (2-3 times a } \\
\text { week) }\end{array}$ & $\begin{array}{c}\text { Frequently (1-2 } \\
\text { times a day) }\end{array}$ & $\begin{array}{l}\text { Very frequently } \\
\text { (>2times a day) }\end{array}$ \\
\hline 12 & $\begin{array}{l}\text { How often do you experi- } \\
\text { ence harassment/violence } \\
\text { in the workplace? }\end{array}$ & $\begin{array}{l}\text { Very frequently } \\
\text { (>2times a day) }\end{array}$ & $\begin{array}{l}\text { Frequently (1-2 } \\
\text { times a day) }\end{array}$ & $\begin{array}{l}\text { Occasionally } \\
\text { (2-3 times a } \\
\text { week) }\end{array}$ & $\begin{array}{c}\text { Rarely (2-3 } \\
\text { times a month) }\end{array}$ & $\begin{array}{l}\text { Very rarely (1 in } \\
\text { a month or less) }\end{array}$ & Not at all \\
\hline 13 & $\begin{array}{l}\text { How frequently do you } \\
\text { encounter any form of } \\
\text { abuse in the workplace? }\end{array}$ & $\begin{array}{l}\text { Very frequently } \\
\text { (>2times a day) }\end{array}$ & $\begin{array}{l}\text { Frequently (1-2 } \\
\text { times a day) }\end{array}$ & $\begin{array}{l}\text { Occasionally } \\
\text { (2-3 times a } \\
\text { week) }\end{array}$ & $\begin{array}{c}\text { Rarely (2-3 } \\
\text { times a month) }\end{array}$ & $\begin{array}{l}\text { Very rarely ( } 1 \text { in } \\
\text { a month or less) }\end{array}$ & Not at all \\
\hline 14 & $\begin{array}{l}\text { How often do you experi- } \\
\text { ence any symptom of car- } \\
\text { diovascular diseases such } \\
\text { as shortness of breath or } \\
\text { chest pain? }\end{array}$ & $\begin{array}{l}\text { Very frequently } \\
\text { (>2times a day) }\end{array}$ & $\begin{array}{l}\text { Frequently (1-2 } \\
\text { times a day) }\end{array}$ & $\begin{array}{l}\text { Occasionally } \\
\text { (2-3 times a } \\
\text { week) }\end{array}$ & $\begin{array}{c}\text { Rarely (2-3 } \\
\text { times a month) }\end{array}$ & $\begin{array}{l}\text { Very rarely ( } 1 \text { in } \\
\text { a month or less) }\end{array}$ & Not at all \\
\hline 15 & $\begin{array}{l}\text { How often do you have } \\
\text { any musculoskeletal dis- } \\
\text { orders such as low back } \\
\text { pain? }\end{array}$ & $\begin{array}{l}\text { Very frequently } \\
\text { (>2times a day) }\end{array}$ & $\begin{array}{l}\text { Frequently (1-2 } \\
\text { times a day) }\end{array}$ & $\begin{array}{l}\text { Occasionally } \\
\text { (2-3 times a } \\
\text { week) }\end{array}$ & $\begin{array}{c}\text { Rarely (2-3 } \\
\text { times a month) }\end{array}$ & $\begin{array}{l}\text { Very rarely ( } 1 \text { in } \\
\text { a month or less) }\end{array}$ & Not at all \\
\hline 16 & $\begin{array}{l}\text { How often do you experi- } \\
\text { ence good health? }\end{array}$ & Not at all & $\begin{array}{l}\text { Very rarely ( } 1 \text { in a } \\
\text { month or less) }\end{array}$ & $\begin{array}{c}\text { Rarely (2-3 } \\
\text { times a month) }\end{array}$ & $\begin{array}{l}\text { Occasionally } \\
\text { (2-3 times a } \\
\text { week) }\end{array}$ & $\begin{array}{c}\text { Frequently (1-2 } \\
\text { times a day) }\end{array}$ & $\begin{array}{l}\text { Very frequently } \\
\text { (>2times a day) }\end{array}$ \\
\hline 17 & $\begin{array}{l}\text { How often do you suffer } \\
\text { any critical medical con- } \\
\text { dition? }\end{array}$ & $\begin{array}{l}\text { Very frequently } \\
\text { (>2times a day) }\end{array}$ & $\begin{array}{l}\text { Frequently (1-2 } \\
\text { times a day) }\end{array}$ & $\begin{array}{l}\text { Occasionally } \\
\text { (2-3 times a } \\
\text { week) }\end{array}$ & $\begin{array}{c}\text { Rarely (2-3 } \\
\text { times a month) }\end{array}$ & $\begin{array}{l}\text { Very rarely ( } 1 \text { in } \\
\text { a month or less) }\end{array}$ & Not at all \\
\hline
\end{tabular}




\begin{tabular}{|c|c|c|c|c|c|c|c|}
\hline 18 & $\begin{array}{l}\text { How often do you feel } \\
\text { satisfied or happy with } \\
\text { your job? }\end{array}$ & Not at all & $\begin{array}{l}\text { Very rarely ( } 1 \text { in a } \\
\text { month or less) }\end{array}$ & $\begin{array}{c}\text { Rarely (2-3 } \\
\text { times a month) }\end{array}$ & $\begin{array}{l}\text { Occasionally } \\
\text { (2-3 times a } \\
\text { week) }\end{array}$ & $\begin{array}{c}\text { Frequently (1-2 } \\
\text { times a day) }\end{array}$ & $\begin{array}{l}\text { Very frequently } \\
\text { (>2times a day) }\end{array}$ \\
\hline 19 & $\begin{array}{l}\text { How often are you com- } \\
\text { mitted to your job? }\end{array}$ & Not at all & $\begin{array}{l}\text { Very rarely (1 in a } \\
\text { month or less) }\end{array}$ & $\begin{array}{c}\text { Rarely (2-3 } \\
\text { times a month) }\end{array}$ & $\begin{array}{l}\text { Occasionally } \\
\text { (2-3 times a } \\
\text { week) }\end{array}$ & $\begin{array}{c}\text { Frequently (1-2 } \\
\text { times a day) }\end{array}$ & $\begin{array}{l}\text { Very frequently } \\
\text { (>2times a day) }\end{array}$ \\
\hline 20 & $\begin{array}{l}\text { How often are you able } \\
\text { to influence decisions } \\
\text { regarding your work? }\end{array}$ & Not at all & $\begin{array}{l}\text { Very rarely (1 in a } \\
\text { month or less) }\end{array}$ & $\begin{array}{c}\text { Rarely (2-3 } \\
\text { times a month) }\end{array}$ & $\begin{array}{l}\text { Occasionally } \\
\text { (2-3 times a } \\
\text { week) }\end{array}$ & $\begin{array}{c}\text { Frequently (1-2 } \\
\text { times a day) }\end{array}$ & $\begin{array}{l}\text { Very frequently } \\
\text { (>2times a day) }\end{array}$ \\
\hline
\end{tabular}

